Ruth L. Healey, UNIVERSITY OF CHESTER, r.healey@chester.ac.uk

Tina Bass, COVENTRY UNIVERSITY, bsx178@coventry.ac.uk Jay Caulfield, MARQUETTE UNIVERSITY, jay.caulfield@marquette.edu Adam Hoffman, UNIVERSITY OF DUBUQUE,AHoffman@dbq.edu

Michelle K. McGinn, BROCK UNIVERSITY, mcginn@brocku.ca Janice Miller-Young, MOUNT ROYAL UNIVERSITY, jmyoung@mtroyal.ca Martin Haigh, OXFORD BROOKES UNIVERSITY, mhaigh@brookes.ac.uk

\title{
Being Ethically Minded: Practising the Scholarship of Teaching and Learning in an Ethical Manner
}

\begin{abstract}
The authors propose a working definition of ethical Scholarship of Teaching and Learning (SoTL), advance an ethical framework for SoTL inquiry, and present a case study that illustrates the complexity of ethical issues in SoTL. The Ethical SoTL Matrix is a flexible framework designed to support SoTL practitioners, particularly in the formative stages of their inquiries. Three dominant ethical traditions form the basis of the matrix: teleological or pragmatic, external, and deontological. The key message of the paper is that SoTL practitioners should reflect on different perspectives in their efforts to do what is right in any given situation. The matrix introduces three dominant ethical traditions, but SoTL practitioners may ultimately move beyond these traditions to explore a range of ethical considerations appropriate to their projects and disciplines.
\end{abstract}

\section{KEYWORDS}

ethical approaches, ethically minded, ethical research, ethical scholarship of teaching and learning

Practising the Scholarship of Teaching and Learning (SoTL) in an ethical manner raises complex issues and challenges for educator-scholars to consider and address. This paper draws upon existing debates around ethical issues within SoTL and builds upon the principles described in Maclean and Poole (2010) and Burman and Kleinsasser (2004) to offer a flexible framework to support SoTL practitioners to be ethically minded as they conduct studies in any discipline or context.

Hutchings (2003) noted that concerns about ethical complexities in SoTL should not be taken "to suggest that something is amiss in the scholarship of teaching and learning... Attention to ethics is something we expect as a field of study or practice evolves" (p. 28). However, a decade later, despite expanding engagement in SoTL, discussion about the ethical issues faced by SoTL practitioners and strategies to manage these issues remains limited. One of the challenges is that a majority of SoTL practitioners lack formal training in ethics because they do not have philosophy backgrounds, come from disciplines where undergraduate or graduate training in human research ethics is the norm, or work 
with human participants in their disciplinary scholarship (Burman \& Kleinsasser, 2004; Maclean \& Poole, 2010). This means many SoTL practitioners are unfamiliar with the ethical obligations of research with human participants (Fenton \& Szala-Meneok, 2010).

A wide range of ethical guidelines for research involving human participants has been produced across the social sciences (Israel \& Hay, 2006). The basic principles underlying these guidelines include respect, free and informed consent, conflict of interest declarations, privacy and confidentiality, and risk-to-benefit analysis. When these principles are applied to SoTL, the issues become particularly complex. This complexity relates primarily to the dual role of most SoTL practitioners as both educators and scholars (Pecorino \& Kincaid, 2007). Our framework goes beyond identifying principles for "good" practice, to considering ethical issues in SoTL from a holistic perspective. As Maclean and Poole (2010) argue, "ethical challenges should be viewed as opportunities to examine the critical relationships between teachers and students and how they affect learning” (p. 9).

In this paper, we develop a working definition of ethical SoTL and propose an ethical framework for SoTL inquiry, which is then explored through a sample case study that illustrates the complexity of ethical issues in SoTL. The work is based upon an analysis of the literature and our personal experiences as an international group of authors (Canada, UK, and USA) from a range of disciplines (Business Studies, Environmental Science, Geography, Higher Education, Leadership, and Mechanical Engineering), considering three Western ethical traditions (teleological or pragmatic, external, and deontological).

\section{WHAT IS ETHICAL SOTL?}

In order to define ethical SoTL, it is necessary to explain our interpretation of both SoTL and ethics. We argue that SoTL is the process of exploring, researching, developing, refining, reflecting upon, and communicating better ways and means of producing, promoting, and enhancing scholarly learning and teaching in ways that are ethically reasoned and inclusive. Of course, the definition of SoTL has been and will continue to be widely debated (Gale, 2009; Potter \& Kustra, 2011). As Healey (2003) argued, "it is unrealistic to expect a single definition to emerge" (p. 16), for the concept remains fluid, evolving, and open to plural interpretation. However, the literature is explicit that scholarly teaching is the foundation stone of SoTL-especially scholarly teaching that focuses on the individual's own classroom practice and experience (Potter \& Kustra, 2011). Kreber (2002) defined scholars of teaching as those who "draw on formal and personal sources of knowledge construction about teaching, effectively combine this with their knowledge of the discipline to construct pedagogical content knowledge, continuously further this knowledge through self-regulated learning processes, and validate their knowledge through peer-review" (p. 18).

Diamond (2002) argued that scholarly teaching becomes SoTL when it exhibits a high level of disciplinary expertise, addresses clear goals and appropriate methodology in a scholarly manner, demonstrates results that are effectively documented and replicable, is innovative and evaluated through honest reflection and scholarly critique (including external peer review), and communicates messages to and relevant for the wider community of educators. Hence, SoTL's concerns expand beyond scholarly teaching toward wider issues of institutional practice and educational issues that affect human society at all levels. This raises the question of what constitutes ethical SoTL.

Ethics involve a combination of codes for determining what one ought to do and why 
one ought to do that (Perrett, 1998). They provide the tools needed to develop practical compromises between what is correct universally and what is right in particular situations. As Smith (1999) explained, ethics require "the application of theories of justice and human good, however tentative, to the facts of a local situation" (p. 288). Frequently, ethical choices are tested by contradictory loyalties. Often the choice to be made is less between "right" and "wrong" and more between "right" and "not wrong" or between "right" and "also right” (Badaracco, 1998). Kidder (1985) posed four common right-versus-right ethical dilemmas, which involve choices between truth and loyalty, individual and collective good, short- and long-term consequences, or justice and mercy.

Ethical decision making is dogged by worries about whether it is the ends or the means that should take precedence or whether, as Gandhi (1924/2002) maintained, means are merely "ends in the making," and hence means and ends are the same thing. Some scholars concern themselves with whether the goals of ethical behaviour are defined by optimizing happiness for the greatest number, as in Bentham-ite Utilitarianism; reducing the causes of sorrow, as in Buddhism; or the selfless performance of duty, as in the Hindu Bhagavadgita. As the philosopher Blackburn (2001) pointed out, for many previous thinkers, "the central concern was the state of the soul, meaning some personal state of justice or harmony" (p.3), whereas many modern societies operate under an understanding that when social arrangements are just, they can function regardless of the private vices within them.

In Blackburn's view, an ethical climate is different from a moralizing one because "we do not like being told what to do. We want to enjoy our lives and we want to enjoy them with a good conscience" (p. 6). In a sense, this is the root of "reciprocal ethics." An example is the Golden Rule, which admonishes all to "treat others as we wish others to treat us” (Parliament of the World's Religions, 1993, p. 3). Wilber, Patten, Leonard, and Morelli (2008) suggested moving beyond the Golden Rule toward a Platinum Rule, which is to "treat others as they would like to be treated" (p. 259). Certainly, ethical awareness is a key skill for reflective practitioners and is presented here as a critical concern for those who evaluate or develop the practices of scholarly teaching and of SoTL.

An ethical person or scholar is clearly not made or defined by one choice or reaction to one situation; rather an ethical person is revealed through reactions or choices, often subconscious, hundreds of times each and every day. Such ethical foundations can only be constructed by gaining knowledge of who one is, what one stands for, and what one's purpose is in life. Gardner, Csikszentmihalyi, and Damon (2001), for example, encouraged people to invoke the universal mirrors test and to ask themselves regularly, "What would it be like to live in a world if everyone were to behave in the way that I have?" (p. 12).

Ethics in education cannot be prescriptive because ethical behaviour can be viewed and approached from a multitude of perspectives. For an ethical SoTL practitioner, it is important to consider how to foster ethical reflection in learners without imposing a particular viewpoint; and how to create an ethical climate (Blackburn, 2001) in the classroom, the university, and the wider world. Ethical SoTL scholars aim to describe ways and means to build ethical fitness in themselves and in others (Kidder, 1985), but are also very aware that ethics cannot be communicated unless they are also applied actively by those who teach.

In summary, SoTL becomes ethical SoTL, when a scholar exhibits well-developed personal "ethical fitness" and operates in an "ethical climate." In particular, scholars must 
demonstrate they have (a) conscientiously and thoroughly considered the ethical implications and choices within their work, and (b) fostered personal ethical reflection in others (students or academic peers) without being normative or prescriptive. These two points shift the emphasis from the scholar to the scholarship and add another dimension of responsibility, that is, to develop work that contributes positively to society. This discussion emphasizes the importance of reflection within the practice of SoTL, but does not yet consider the specific challenges of SoTL practitioners occupying dual roles as both educators and scholars.

\section{REFLECTING ON ETHICAL SOTL CHALLENGES}

As the purpose of reflection expands from enhancing one's own professional practice to providing information for others, the undertaking is no longer simply about professional practice and professional development; it becomes a research undertaking with concomitant obligations and expectations, including considerations related to evidentiary standards, students as potential human participants, and the privacy and confidentiality of data. Often SoTL inquiry occurs within practitioners' own classrooms, placing them in a dual role as educators and scholars, and placing students in a dual role as members of the student body and of the researched group. Students are not always aware of the professional or personal obligations their instructors hold and may not understand the wider goals for scholarly teaching or SoTL. This may lead to a variety of ethical challenges, the most significant being that the actions that are most appropriate for research may not be most appropriate for teaching. The framework proposed in our Ethical SoTL Matrix offers SoTL practitioners opportunities to reflect upon these potential issues from a range of perspectives, helping them to be ethically minded throughout their inquiry.

\section{THE ETHICAL SOTL MATRIX}

SoTL practitioners originate from all disciplines, so SoTL inquiries are likely to come from multiple perspectives, employing an array of research methods. The Ethical SoTL Matrix (Table 1) _ inspired by Stutchbury and Fox (2009) and Mepham, Kaiser, Thorstensen, Tomkins, and Millar (2006) — provides the flexibility to adapt to multiple disciplines and multiple research methods, while providing guidelines for reflection without being prescriptive. The purpose of the matrix is to encourage ethical reflection regarding significant stakeholders when engaged in SoTL inquiry.

We use the term stakeholders to identify those individuals, groups, organizations, and institutions that have an interest in and are affected by the decisions made during SoTL inquiry. We use this inclusive term to provide flexibility in the matrix to encompass the perspectives of any of these groups. It is likely that some of the more common stakeholders in SoTL inquiry will include the educator-scholars themselves, the research participants, the broader student community, other educators, and educational administrators. We use the terms EDUCATOR-scholars and educator-SCHOLARS to differentiate between the teaching and research aspects of the inquiry and to address specific differences in the ethical considerations for each of these roles. The term educator-scholar is used when the teaching and research aspects of inquiry are equally relevant.

The columns of the matrix highlight key Western ethical traditions - teleological or pragmatic, external, and deontological - that may generate decision actions. The teleological or pragmatic ethical tradition emphasizes the consequences of actions. As White (1993) 
Table 1: Ethical SoTL Matrix

ETHICAL TRADITIONS

\begin{tabular}{|c|c|c|c|}
\hline \multirow[t]{2}{*}{ STAKEHOLDERS } & TELEOLOGICAL & EXTERNAL & DEONTOLOGICAL \\
\hline & $\begin{array}{l}\text { OR PRAGMATIC } \\
\text { To what extent do potential } \\
\text { consequences of the SoTL } \\
\text { inquiry help or hurt } \\
\text { stakeholders in the short and } \\
\text { long run? }\end{array}$ & $\begin{array}{l}\text { To what extent are } \\
\text { external factors } \\
\text { considered? }\end{array}$ & $\begin{array}{l}\text { To what extent does the } \\
\text { SoTL inquiry demonstrate } \\
\text { respect for person, } \\
\text { autonomy, and choice? }\end{array}$ \\
\hline $\begin{array}{l}\text { Students and } \\
\text { the institutional } \\
\text { community }\end{array}$ & $\begin{array}{l}\text { What short- and long- } \\
\text { term consequences can } \\
\text { be expected for students } \\
\text { and the institutional } \\
\text { community as a result of } \\
\text { the SoTL inquiry? }\end{array}$ & $\begin{array}{l}\text { To what extent does } \\
\text { the SoTL inquiry } \\
\text { reflect external } \\
\text { factors for students } \\
\text { and the institutional } \\
\text { community? }\end{array}$ & $\begin{array}{l}\text { To what extent does the } \\
\text { SoTL inquiry contribute } \\
\text { to the intellectual } \\
\text { development of students } \\
\text { and the institutional } \\
\text { community while at the } \\
\text { same time demonstrating } \\
\text { respect for person, } \\
\text { autonomy, and choice? }\end{array}$ \\
\hline $\begin{array}{l}\text { EDUCATOR- } \\
\text { scholar and the } \\
\text { teaching community }\end{array}$ & $\begin{array}{l}\text { What short- and long- } \\
\text { term consequences can be } \\
\text { expected for educators and } \\
\text { the teaching community } \\
\text { as a result of the SoTL } \\
\text { inquiry? }\end{array}$ & $\begin{array}{l}\text { To what extent does } \\
\text { the SoTL inquiry } \\
\text { promote efficient } \\
\text { use of resources by } \\
\text { the educator and the } \\
\text { teaching community? }\end{array}$ & $\begin{array}{l}\text { To what extent does the } \\
\text { SoTL inquiry contribute } \\
\text { to enhanced teaching and } \\
\text { learning while respecting } \\
\text { person, autonomy, and } \\
\text { choice? }\end{array}$ \\
\hline $\begin{array}{l}\text { Educator- } \\
\text { SCHOLAR and the } \\
\text { research community }\end{array}$ & $\begin{array}{l}\text { What short- and long- } \\
\text { term consequences can be } \\
\text { expected for scholars and } \\
\text { the research community } \\
\text { as a result of the SoTL } \\
\text { inquiry? }\end{array}$ & $\begin{array}{l}\text { To what extent does } \\
\text { the SoTL inquiry } \\
\text { meet the standards for } \\
\text { credible evidence in } \\
\text { the discipline where } \\
\text { the SoTL inquiry is } \\
\text { conducted? }\end{array}$ & $\begin{array}{l}\text { To what extent does the } \\
\text { SoTL inquiry provide } \\
\text { credible evidence } \\
\text { to scholars and the } \\
\text { research community } \\
\text { while respecting person, } \\
\text { autonomy, and choice? }\end{array}$ \\
\hline
\end{tabular}

explained, "the moral character of actions depends on the simple, practical matter of the extent to which actions actually help or hurt people. Actions that produce more benefits than harm are 'right'; those that don't are 'wrong'” (p. 4). This tradition is the basis for risk-to-benefit analyses that predominate in discussions of research ethics. It arises from the work of Jeremy Bentham (1748-1832) and John Stuart Mill (1806-1873). According to Mill (as cited in White, 1993), one must consider not only the immediate result of actions but the long-term result as well. Thus, SoTL practitioners need to attend to the immediate and the most likely future results of their actions in terms of benefiting versus harming human welfare.

The external ethical tradition emphasizes how decisions have impacts beyond the immediate action to consider the potential external consequences. Norton (2008) captures this tradition well in the example of Aldo Leopold's economic decision to eradicate a population of wolves to solve a short-term economic problem for nearby ranchers. This action led to an overpopulation of deer, resulting in a loss of vegetation and, through erosion, a loss of topsoil. This ethical tradition considers the potential external impact of actions. Such thinking allows one to balance thinking about an action while at the same time "accepting responsibility for all future effects of choices foreseeable" (Norton, 2008, p. 586). In other words, pluralistic thinking within this ethical tradition demands simul- 
taneous consideration of multiple external factors for the near future and the long run. Pickett and Cadenasso (2002) argued from this perspective that "the precision and narrow focus of technical terms is eschewed in favor of richness of connotation and in support of societally important, if sometimes controversial, values" (p. 6). This tradition considers the consequences of action in the same way as the pragmatic tradition, but pushes the researcher to consider the broader contextual impact, rather than just the immediate or local effects of a course of action.

The deontological ethical tradition does not consider the consequences of action. Instead, it focuses on the act itself as having moral implications. In other words, through reason, the act itself is judged as either moral or immoral; the consequences of the act are immaterial as related to that judgment. The most well-known thinker associated with deontological ethics is Immanuel Kant (1724-1804). Kant (1785/2005) stated that moral obligation "must not be sought in the nature of man or in the circumstances in which he is placed, but sought a priori solely in the concepts of pure reason" (p. 5). The basis of Kantian ethics is that one has a duty to respect individuals as autonomous human beings as a result of their existence as such. Thus, one has an inherent duty to never use individuals as a means to an end, regardless of consequences: "Treating people as 'ends' requires seeing them as autonomous beings who are entitled to control their own fate and not to be deceived or manipulated" (White, 1993, p. 10). Respect for person, autonomy, and choice are critical considerations from a deontological perspective.

There are many other ethical traditions that could be considered in this discussion. For instance, postmodernist ethics (Rothfork, 1995), virtue ethics (Hursthouse, 1999), relational ethics (Noddings, 2012), and feminist ethics (Whisnant \& DesAutels, 2008) could each add new dimensions. However, this paper emphasizes guiding SoTL practitioners to consider and select between different courses of action. The small selection presented here provides a range of possibilities that are immediate and practical, without overwhelming readers with considerations from every possible tradition. The key message is that SoTL practitioners should reflect on different perspectives as they consider possible actions in their efforts to do what is right in any given situation.

The benefit of this matrix is that it can be used for any type of inquiry, guiding novices and experienced practitioners to be ethically minded as they undertake SoTL inquiry. To illustrate, we present one sample case study from the field of physics education.

\section{APPLYING THE ETHICAL SOTL MATRIX: THE PHYSICS FORMULA SHEET CONTROLLED STUDY}

Using formula sheets during exams is fairly standard in first-year physics courses, although there is disagreement in the literature about the extent to which this is an effective practice. Some argue that conceptual understanding can be emphasized by freeing students from the demands of memorization, while others argue that in order to think, basic facts need to be internalized so there is something to think about (Rehfuss, 2003). Morris and Scott (2012) asked the question, does memorization of basic facts in physics enhance, detract, or make no difference in learning outcomes as measured by performance on examinations? To address this question, the two educator-scholars designed an intervention study that was implemented in two sections of a physics course, involving three midterm examinations that occurred over one semester. The first midterm was administered according to standard practice where all students were provided with a for- 
mula sheet. For the second and third midterms, student participants were randomly divided into two groups: group A wrote the second midterm without a formula sheet and the third midterm with a formula sheet, while group B did the opposite. The separation of each class into two groups controlled for the possibility that midterms two and three were inadvertently of varying difficulty. At the end of the semester, the educator-scholars compared midterm marks with and without the formula sheet, and also analyzed final exam marks to study long-term retention and understanding. Table 2 highlights aspects of the ethical matrix for this SoTL inquiry.

This example was chosen because it showcases divergent considerations with respect to students and disciplinary colleagues. A key consideration in designing the study was to produce evidence that would be scientifically rigorous and credible to the educatorSCHOLARS and their research community. However, implementing a controlled study in one's own class has inherent ethical challenges. In order to achieve scientific rigour, or in other words to achieve the pragmatic and external goals of doing credible research that attends to disciplinary standards, the educator-SCHOLARS wanted to randomly assign students to two different groups, and they needed enough student participants to achieve significant results. To satisfy the latter criterion, the study took place in two concurrent sections of the same course and required a high level of coordination between

Table 2: Ethical SoTL Matrix for the Physics Formula Sheet Study

\begin{tabular}{|c|c|c|c|}
\hline \multirow[b]{2}{*}{ STAKEHOLDERS } & \multicolumn{3}{|c|}{ ETHICAL TRADITIONS } \\
\hline & $\begin{array}{l}\text { TELEOLOGICAL } \\
\text { OR PRAGMATIC } \\
\text { To what extent do potential } \\
\text { consequences of the SoTL } \\
\text { inquiry help or hurt stakeholders } \\
\text { in the short and long run? }\end{array}$ & $\begin{array}{l}\text { To what extent are external } \\
\text { factors considered? }\end{array}$ & $\begin{array}{l}\text { To what extent does } \\
\text { the SoTL inquiry } \\
\text { demonstrate respect for } \\
\text { person, autonomy, and } \\
\text { choice? }\end{array}$ \\
\hline $\begin{array}{l}\text { Students and } \\
\text { the institutional } \\
\text { community }\end{array}$ & $\begin{array}{l}\text { - Control differential risks } \\
\text { to participating and non- } \\
\text { participating students that } \\
\text { arise from uncertainty } \\
\text { about whether writing a } \\
\text { midterm without a formula } \\
\text { sheet enhances or hinders } \\
\text { performance } \\
\text { - Control potential for bias in } \\
\text { treatment or undue influence } \\
\text { from the instructor }\end{array}$ & $\begin{array}{l}\text { - Count the best two of } \\
\text { three midterm marks to } \\
\text { relieve student concerns } \\
\text { - Communicate findings } \\
\text { to broader student } \\
\text { community } \\
\text { - Adopt departmental } \\
\text { practice consistent with } \\
\text { findings }\end{array}$ & $\begin{array}{l}\text { - Provide a satisfying } \\
\text { learning experience } \\
\text { - Respect student } \\
\text { autonomy by } \\
\text { providing free } \\
\text { choice to participate } \\
\text { or not } \\
\text { - Ensure informed } \\
\text { consent } \\
\text { - Offer students } \\
\text { control over data } \\
\text { (confidentiality, } \\
\text { withdrawal, etc.) }\end{array}$ \\
\hline $\begin{array}{l}\text { EDUCATOR- } \\
\text { scholar and the } \\
\text { teaching community }\end{array}$ & $\begin{array}{l}\text { - Build respect for SoTL } \\
\text { inquiry from students and } \\
\text { teaching colleagues }\end{array}$ & $\begin{array}{l}\text { - Collaborate with } \\
\text { colleagues to provide } \\
\text { robust assessment in a } \\
\text { single semester }\end{array}$ & $\begin{array}{l}\text { - Reflect on } \\
\text { pedagogical } \\
\text { practices and their } \\
\text { impact on students }\end{array}$ \\
\hline $\begin{array}{l}\text { Educator- } \\
\text { SCHOLAR and the } \\
\text { research community }\end{array}$ & $\begin{array}{l}\text { - Achieve credible research } \\
\text { through controlled design } \\
\text { that counterbalances } \\
\text { treatments across midterms }\end{array}$ & $\begin{array}{l}\text { - Attend to disciplinary } \\
\text { standards favouring } \\
\text { controlled experiments } \\
\text { - Secure clearance from } \\
\text { ethics review committee }\end{array}$ & $\begin{array}{l}\text { Produce evidence } \\
\text { for improved } \\
\text { examination } \\
\text { strategies in the } \\
\text { discipline }\end{array}$ \\
\hline
\end{tabular}


the two educator-scholars. In the past, the course had either two or three midterms. To address the question of whether different content on subsequent midterms would confound the results, they counterbalanced the order of formula sheet use so one group wrote one midterm with a formula sheet and the subsequent midterm without, and the other group did the opposite.

The effect of the proposed intervention on students was equally important in designing the study. Simply imposing the intervention on the whole class would mean there would be no possibility for students to not participate in the study, violating the deontological goal of ensuring free consent. Therefore, the educator-scholars decided to have three midterms. All students, whether participating in the study or not, wrote the first midterm with a formula sheet, as per usual. Participating students wrote one remaining midterm with a formula sheet and one without, depending upon their group assignment. Non-participants wrote the second midterm with a formula sheet, but were given the option of writing the third midterm with or without a formula sheet. For all students, the lowest midterm mark was dropped in the calculation of final grades. In this way, the instructors ensured that whether using a formula sheet during the midterm exams was beneficial or not, students would be exposed to no additional risk compared to the traditional organization of the class, thus meeting the pragmatic goal of managing potential risk to participating and non-participating students.

In addition to the design considerations above, other measures were put in place so the identities of student participants were kept confidential from their own instructor until grades were submitted. This addressed a deontological concern with respecting the participants. Each educator-SCHOLAR acted as lead researcher for the other class, which included recruiting, assigning the groups, and invigilating the midterms. However, each EDUCATOR-scholar marked his own students' midterms, according to an agreed-upon rubric. Not knowing which students were participating eliminated the potential for bias in marking, and reduced the potential for students to feel unduly influenced to participate. Once the semester was over and the final grades submitted, the educator-scholars revealed to each other which students took part in the study, and the testing group to which they belonged. Each educator-SCHOLAR then analyzed the results of participants in his own section and shared anonymized results with the other educator-SCHOLAR.

As this discussion demonstrates, fully considering the effects on various stakeholders from different ethical traditions enhanced the integrity of the research and minimized the potential risks. Morris and Scott (2012) discovered the use of formula sheets did not affect overall course performance; however, they suspect students had higher scores for conceptual questions when they did not use a formula sheet, which is the focus of their next SoTL inquiry. These results matter to students, EDUCATOR-scholars, educatorSCHOLARS, and the wider community. As a result of their study, Morris and Scott demonstrated ethical mindedness while discovering useful information to inform their future examination practices.

\section{CONCLUSION}

In this paper, we developed a working definition of ethical SoTL and proposed an ethical framework for SoTL inquiry, which we then explored through a case study illustrating the complexity of ethical issues in SoTL. The definition of ethical SoTL presented here focused on developing personal "ethical fitness" and an "ethical climate" to operate 
within. Our emphasis was on scholarship and educator-scholars' responsibilities for contributing to society. The Ethical SoTL Matrix offers SoTL practitioners the opportunity to reflect on their inquiries in a holistic manner and therefore to consider and respond to a range of potential issues without being forced to operate within any one scholarly paradigm or ethical tradition.

The Ethical SoTL Matrix draws attention to three dominant ethical traditions and three categories of stakeholders. Contemplating multiple perspectives foregrounds different aspects than would be evident by considering one tradition or one stakeholder in isolation and, in this way, it supports SoTL practitioners to make informed choices in the face of right-versus-right dilemmas. The matrix is a catalyst for SoTL practitioners to be ethically minded. SoTL practitioners are encouraged to use the matrix to prompt ethical reflections related to the three traditions and the identified stakeholders, but not to confine themselves to these perspectives. SoTL practitioners should explore a range of ethical considerations appropriate to their projects and disciplines as they reflect on their actions and the rationale for those actions.

Our experience indicates that research with students is often deemed "different" from other types of research, and sometimes the ethical obligations for work with human participants are avoided or even swept aside. This situation seems to arise because many SoTL inquiries fall somewhere between quality assurance or enhancement and traditional academic research, especially when educator-scholars research their own teaching. Understanding of SoTL as either quality enhancement or research influences the extent of ethical review that is institutionally mandated. For example, in some institutions, review committees known as Institutional Review Boards (IRBs), Research Ethics Boards (REBs), or Research Review Committees (RRCs), among other names, may give blanket clearance for analyses of student data gathered for instructional purposes or for all SoTL inquiry defined as quality enhancement to improve teaching and learning. For other institutions, the same work would require a full, formal review or even be rejected as too ethically challenging.

Regardless of the requirements or expectations for review by any institutional committee, the framework presented here offers guidance to facilitate reflection with respect to the range of stakeholders involved in SoTL inquiry as educator-scholars plan ethically robust assessment of their instructional practices. The Ethical SoTL Matrix offers a framework to support reflection whether preparing for ethical review or planning SoTL inquiry. Engaging in the type of reflection we argue for in this paper offers opportunities to work on changing cultures in SoTL, moving away from viewing ethics as a quality assurance process to recognizing ethical reflection as a quality enhancement process. Being ethically minded is about striving to make the right choices not simply following institutional regulations.

Ruth L. Healey is a Senior Lecturer in Human Geography at the University of Chester, UK.

Tina Bass is a Senior Lecturer in Strategy and Management at Coventry Business School, UK.

Jay Caulfield is an Associate Professor of Leadership and Ethics and Associate Dean for Marquette University's College of Professional Studies.

Adam Hoffman is an Associate Professor of Environmental Chemistry at the University of Dubuque (UD), USA. 
Healey, Bass, Caulfield, Hoffman, McGinn, Miller-Young, Haigh

Michelle K. McGinn is a Professor of Education at Brock University, St. Catharines, Canada.

Janice Miller-Young is an Associate Professor in engineering at Mount Royal University (MRU), Canada, and is the current chair of MRU's human research ethics board.

Martin Haigh is a Professor of Geography at Oxford Brookes University and a National Teaching Fellow, UK.

\section{REFERENCES}

Badaracco, J. L., Jr. (1998). The discipline of building character. Harvard Business Review, 76(2), 114-124.

Blackburn, S. (2001). Ethics: A very short introduction. Oxford, UK: Oxford University Press.

Burman, M. E., \& Kleinsasser, A. (2004). Ethical guidelines for use of student work: Moving from teaching's invisibility to inquiry's visibility in the scholarship of teaching and learning. The Journal of General Education: A Curricular Commons of the Humanities and Sciences, 53, 59-79. doi:10.1353/jge.2004.0018

Diamond, R. M. (2002). The mission-driven faculty reward system. In R. M. Diamond (Ed.), Field guide to academic leadership (pp. 271-294). San Francisco, CA: Jossey-Bass.

Fenton, N. E., \& Szala-Meneok, K. (2010). Research on teaching and learning guidebook. Hamilton, ON, Canada: McMaster University.

Gale, R. (2009). Asking questions that matter ... asking questions of value. International Journal for the Scholarship of Teaching and Learning, 3(2). Retrieved from http://academics .georgiasouthern.edu/ijsotl/v3n2/invited_essays/PDFs/InvitedEssay_Gale.pdf

Gandhi, M. (2002). The essential Gandhi: An anthology of his writings on his life, work, and ideas (L. Fischer, Ed., $2^{\text {nd }}$ ed.). New York, NY: Vintage Spiritual Classics. (Original work published 1924)

Gardner, H., Csikszentmihalyi, M., \& Damon, W. (2001). Good work: When excellence and ethics meet. New York, NY: Basic Books.

Healey, M. (2003). The scholarship of teaching: Issues around an evolving concept. Journal on Excellence in College Teaching, 14(2/3), 5-26.

Hursthouse, R. (1999). On virtue ethics. Oxford, UK: Oxford University Press.

Hutchings, P. (2003). Competing goods: Ethical issues in the scholarship of teaching and learning. Change: The Magazine of Higher Learning, 35(5), 27-33. Retrieved from www.cte .hawaii.edu/handouts/HHhandout.pdf

Israel, M., \& I. Hay (2006). Research ethics for social scientists. Thousand Oaks, CA: Sage.

Kant, I. (2005). Fundamental principles of the metaphysic of morals (T. K. Abbott, Trans.). Retrieved from http://www.gutenberg.org/cache/epub/5682/pg5682.html (Original work published 1785)

Kidder, R. M. (1985). How good people make tough choices: Resolving the dilemmas of ethical living. New York, NY: William Morrow.

Kreber, C. (2002). Teaching excellence, teaching expertise, and the scholarship of teaching. Innovative Higher Education, 27, 5-23. doi:10.1023/A:1020464222360

Maclean, M., \& Poole, G. (2010). An introduction to ethical considerations for novices to re- 
search in teaching and learning in Canada. The Canadian Journal for the Scholarship of Teaching and Learning, 1(2), article 7. doi:10.5206/cjsotl-rcacea.2010.2.7

Mepham, B., Kaiser, M., Thorstensen, E., Tomkins, S., \& Millar, K. (2006). Ethical matrix manual. The Hague, the Netherlands: LEI. Retrieved from http://www.ethicaltools.info/content /ET2\%20Manual\%20EM\%20\%28Binnenwerk\%2045p\%29.pdf

Morris, A., \& Scott, W. (2012, June). The formula sheet in first year physics exams, friend or foe? Paper presented at the Canadian Association of Physicists Congress, Calgary, AB, Canada.

Noddings, N. (2012). The caring relation in teaching. Oxford Review of Education, 38, 771-781. doi:10.1080/03054985.2012.745047

Norton, B. G. (2008). Beyond positivist ecology: Toward an integrated ecological ethics. Science \& Engineering Ethics, 14, 581-592. doi:10.1007/s11948-008-9095-0

Parliament of the World's Religions. (1993). Declaration toward a global ethic. Retrieved from http://www.urbandharma.org/pdf/ethic.pdf

Pecorino, P., \& Kincaid, S. (2007). Why should I care about SOTL? The professional responsibilities of post-secondary educators. International Journal for the Scholarship of Teaching and Learning, 1(1). Retrieved from http://academics.georgiasouthern.edu/ijsotl/v1n1 /essays/pecorino_kincaid/IJ_Pecorino-Kincaid.pdf

Perrett, R. W. (1998). Hindu ethics: A philosophical study. Hilo, HI: University of Hawaii Press.

Pickett, S. T. A., \& Cadenasso, M. L. (2002). The ecosystem as a multidimensional concept: Meaning, model, and metaphor. Ecosystems, 5, 1-10. doi:10.1007/s10021-001-0051-y

Potter, M. K., \& Kustra, E. (2011). The relationship between scholarly teaching and SoTL: Models, distinctions and clarifications. International Journal for the Scholarship of Teaching and Learning, 5(1). Retrieved from http://academics.georgiasouthern.edu/ijsotl/v5n1 /essays_about_sotl/PotterKustra/index.html

Rehfuss, D. E. (2003). Formula sheet caveat. The Physics Teacher, 41(6), 375-376. doi:10.1119 $/ 1.1607822$

Rothfork, J. (1995). Post-modern ethics: Richard Rorty and Michael Polanyi. Southern Humanities Review, 29(1), 15-48. Retrieved from http://oak.ucc.nau.edu/jgr6/rorty.html

Smith, D. M. (1999). Conclusion: Towards a context sensitive ethics. In J. D. Proctor \& D. M. Smith (Eds.), Geography and ethics: Journeys in a moral terrain (pp. 275-288). London, UK: Routledge.

Stutchbury, K., \& Fox, A. (2009). Ethics in educational research: Introducing a methodological tool for effective ethical analysis. Cambridge Journal of Education, 39, 489-504. doi:10 $.1080 / 03057640903354396$

Whisnant, R., \& DesAutels, P. (Eds.). (2008). Global feminist ethics: Feminist ethics and social theory. Lanham, MD: Rowman \& Littlefield.

White, T. (1993). Business ethics: A philosophical reader. New York, NY: Macmillan.

Wilber, K., Patten, T., Leonard, A., \& Morelli, M. (2008). Integral life practice: A 21st-century blueprint for physical health, emotional balance, mental clarity, and spiritual awakening. Boston, MA: Integral. 